\title{
Evaluation of Test Crosses for Identification of Potential Restorers and Maintainers for Development of Rice Hybrids (Oryza sativa L.)
}

\author{
K. Parimala ${ }^{1^{*}}$, Ch. Surender Raju ${ }^{2}$, A.S. Hari Prasad ${ }^{3}$, S. Sudheer Kumar ${ }^{4}$, \\ S. Narender Reddy ${ }^{5}$ and M.H.V. Bhave
}

${ }^{1}$ Seed Research and Technology Centre, PJTSAU, Rajendranagar, Hyderabad -30, India

${ }^{2}$ Rice Research Centre, Rajendranagar, Hyderabad -30, India

${ }^{3}$ ICAR-Indian Institute of Rice Research, Rajendranagar, Hyderabad -30, India

${ }^{4}$ PJTSAU, Rajendranagar, Hyderabad -30, India

${ }^{5}$ College of Agriculture, PJTSAU, Rajendranagar, Hyderabad -30, India

*Corresponding author

\begin{tabular}{|c|c|}
\hline & A B S T R A C T \\
\hline $\begin{array}{l}\text { Ke y w o r d s } \\
\text { Rice Hybrids, } \\
\text { (Oryza sativa L.), } \\
\text { Evaluation of Test } \\
\text { Crosses }\end{array}$ & \multirow{3}{*}{$\begin{array}{l}\text { The investigation was carried out to identify the potential maintainers and restorers in rice } \\
\text { by crossing the one CMS line with } 65 \text { selected genotypes during rabi 2012-13. The } \\
\text { resultant } 65 \text { test crosses were evaluated during kharif } 2013 \text {. A high range of spikelet } \\
\text { fertility was recorded among the hybrids } i . e \text {., from } 0 \text { to } 92.4 \text { per cent which indicated that } \\
\text { restorability varies depending on male parent. Among the } 65 \text { test crosses studied, } 28 \\
\text { genotypes exhibited high spikelet fertility }(>75 \%), 20 \text { were partial fertile }(50 \text { to } 75 \%) \text {, } \\
\text { whereas } 14 \text { genotypes were partial maintainers }(1 \text { to } 50 \%) \text { and three genotypes were } \\
\text { found to be completely sterile }(0 \%) \text {. The identified maintainers can be developed as new } \\
\text { cytoplasmic male sterile lines by repeated back cross breeding with recurrent parent. } \\
\text { Among the } 28 \text { restorers identified, } 12 \text { best restorers with more than } 80 \text { per cent spikelet } \\
\text { fertility were selected for further use in hybrid rice breeding. }\end{array}$} \\
\hline Article Info & \\
\hline $\begin{array}{l}\text { Accepted: } \\
\text { 10 January } 2019 \\
\text { Available Online: } \\
10 \text { February } 2019\end{array}$ & \\
\hline
\end{tabular}

\section{Introduction}

The development and use of hybrid rice varieties on commercial scale using male sterility and fertility restoration system has proved to be a breakthrough in rice improvement. The availability of stable cytoplasmic male sterility and fertility restoring system is vital for commercial exploitation of heterosis in rice. Cytoplasmic genetic male sterile lines introduced from elsewhere may not be well adapted to a given target area. Successful use of hybrid vigour in rice largely depends on the availability of locally developed cytoplasmic genetic male sterile and restorer lines (Kumar et al., 1996). Identification of locally adapted maintainers and restorers which show complete sterility and consistently high degree of restoration of CMS lines would be of great value in commercial hybrid programme, if restoring ability is combined with high combining ability. Earlier researchers viz., Hussain and Sanghera (2012); Singh et al., (2013); 
Veeresha et al., (2013); Bhati et al., (2014); Parmeshwar Kumar et al., (2014); Jamil Hasan et al., (2015); Pankaj Kumar et al., (2015) and Ramesh et al., (2018) evaluated the test crosses in rice to identify the restorer and maintainer reaction and reported varying levels of pollen and spikelet fertility percentage. The establishment of test cross nursery to identify restorers and maintainers is the first step in three line heterosis breeding (Akhter et al., 2008). Use of male sterility system would be appropriate approach for commercial exploitation of heterosis in rice. In view of the above, the present study was conducted to identify the effective fertility restorers and maintainers.

\section{Materials and Methods}

The basic material for the study consists of one cytoplasmic male sterile (CMS) line of IR-79156A and 65 elite rice genotypes obtained from germplasm collection of Rice Research Centre, Rajendranagar, Hyderabad. The CMS line IR-79156A was crossed with 65 diverse male fertile genotypes during rabi, 2012-13. In a crossing block, one CMS line (IR-79156A) and 65 elite rice genotypes were transplanted with a spacing of $20 \times 15 \mathrm{~cm}$ in a row of $6 \mathrm{~m}$ length in three staggered sowings.

Healthy male sterile plant with just emerged panicles were uprooted and potted into plastic buckets filled with mud and were transferred to the crossing chamber. Healthy panicles with florets expected to open on the next day were used for crossing. Top $1 / 3^{\text {rd }}$ portion of each floret was clipped with scissors during evening hours and covered with butter paper bags. Next day morning, panicles ready for anthesis were collected from male parents and used for pollination with CMS lines (female parent). The pollinated spikelets were then covered and labelled. Crossed seeds were collected after four weeks and seeds were dried and preserved.
The resultant 65 test crosses were evaluated in test cross nursery during kharif, 2013. Pollen fertility test was carried out by using the five randomly selected spikelets from each entry. With the help of forceps, the anthers from the spikelets were gently placed on glass slide containing 2\% Iodine Potassium Iodide (IKI) solution. Then the anthers were gently crushed to release the pollen grains and observed under microscope. The pollen fertility (\%) was calculated by using the formula as given below:

Pollen fertility $(\%)=\frac{\begin{array}{l}\text { No. of fertile } \\ \text { pollen grains }\end{array}}{\begin{array}{l}\text { Total No. of } \\ \text { pollen grains }\end{array}} \times 100$

Five panicles were selected randomly from each entry during maturity and spikelet fertility (\%) was calculated by using the following formula:

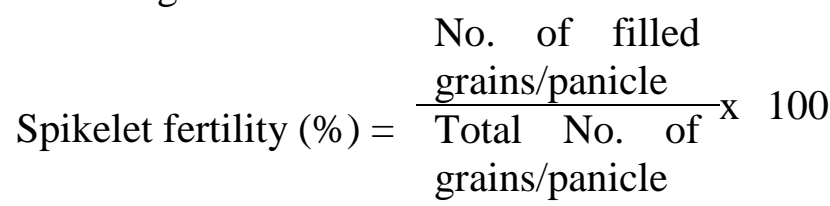

The following criteria for classifying the pollen parents were used as proposed by (Virmani et al., 1997).

\begin{tabular}{|l|c|c|}
\hline Category & $\begin{array}{c}\text { Pollen } \\
\text { fertility (\%) }\end{array}$ & $\begin{array}{c}\text { Spikelet } \\
\text { fertility (\%) }\end{array}$ \\
\hline Maintainers & $0-1$ & 0 \\
\hline $\begin{array}{l}\text { Partial } \\
\text { maintainers }\end{array}$ & $1.1-50$ & $0.1-50$ \\
\hline $\begin{array}{l}\text { Partial } \\
\text { restorers }\end{array}$ & $50.1-80$ & $50.1-75$ \\
\hline Restorers & $>80$ & $>75$ \\
\hline
\end{tabular}

\section{Results and Discussion}

A total of 65 test crosses were evaluated for fertility restorer and maintainer reaction. The performance of the hybrids in test cross nursery for fertility restoration is presented in Table 1 . The pollen fertility of hybrids varied 
from $0.2 \%$ (IR-79156A x WGL-13400) to 94.2\% (IR-79156A x RNR-2456). A high range of spikelet fertility was recorded among the hybrids i.e., from 0 to 92.4 per cent which indicated that restorability varies depending on male parent. Among the 65 test crosses studied, 28 genotypes considered as restorers which exhibited high spikelet fertility (>75\%), 20 genotypes found to be partial fertile (50 to $75 \%$ ), whereas, 14 genotypes were partial maintainers (1 to $50 \%$ ) and three genotypes (IR-79156A x JGL-11727, IR-
79156A x Sumathi and IR-79156A x WGL13400) showed complete spikelet sterility (0 \%). Ali et al., (2014); Pankaj Kumar et al., (2015) and Srijan et al., (2015) reported that fertility restoration reaction of the genotypes varies with genetic background of CMS lines. Umadevi et al., (2010) also reported that this variation may be due to the pollen fertility / restoring genes differ or their penetrance or expressivity differed with genotypes or due to existence of modifiers genes.

Table.1 Fertility restoration study for identification of restorers and maintainers in rice

\begin{tabular}{|c|c|c|c|c|c|c|c|}
\hline S.No. & Crosses & $\begin{array}{c}\text { Days to } \\
50 \% \\
\text { flowering }\end{array}$ & $\begin{array}{c}\text { Pollen } \\
\text { fertility } \\
(\%)\end{array}$ & $\begin{array}{l}\text { No. of } \\
\text { unfilled } \\
\text { grains / } \\
\text { panicle }\end{array}$ & $\begin{array}{l}\text { No. of } \\
\text { filled } \\
\text { grains / } \\
\text { panicle }\end{array}$ & $\begin{array}{c}\text { Spikelet } \\
\text { fertility } \\
(\%)\end{array}$ & $\begin{array}{l}\text { Fertility } \\
\text { reaction }\end{array}$ \\
\hline 1 & IR-79156A x RNR-17462 & 90 & 89.5 & 19.7 & 239.4 & 92.4 & $\mathrm{R}$ \\
\hline 2 & IR-79156A x RNR-15351 & 99 & 85.4 & 19.5 & 235.4 & 92.3 & $\mathrm{R}$ \\
\hline 3 & IR-79156A x RNR-6378 & 99 & 82.6 & 19.8 & 221.5 & 91.8 & $\mathrm{R}$ \\
\hline 4 & IR-79156A x RNR-15038 & 91 & 92.8 & 23.5 & 258.3 & 91.7 & $\mathrm{R}$ \\
\hline 5 & IR-79156A x WGL-583 & 100 & 86.0 & 18.6 & 183.3 & 90.8 & $\mathrm{R}$ \\
\hline 6 & IR-79156A x WGL-48684 & 92 & 84.3 & 19.1 & 184.7 & 90.6 & $\mathrm{R}$ \\
\hline 7 & IR-79156A x NLR-33358 & 81 & 80.7 & 20.7 & 192.5 & 90.3 & $\mathrm{R}$ \\
\hline 8 & IR-79156A x RNR-883 & 113 & 87.5 & 19.7 & 175.6 & 89.9 & $\mathrm{R}$ \\
\hline 9 & IR-79156A x RNR-2456 & 100 & 94.2 & 21.0 & 189.7 & 90.0 & $\mathrm{R}$ \\
\hline 10 & IR-79156A x 6527 & 94 & 86.1 & 23.3 & 195.4 & 89.3 & $\mathrm{R}$ \\
\hline 11 & IR-79156A x WGL-451 & 89 & 90.2 & 16.7 & 135.7 & 89.1 & $\mathrm{R}$ \\
\hline 12 & IR-79156A x RNR-17473 & 92 & 82.5 & 18.0 & 142.3 & 88.8 & $\mathrm{R}$ \\
\hline 13 & IR-79156A x WGL-3962 & 90 & 86.3 & 28.6 & 216.4 & 88.3 & $\mathrm{R}$ \\
\hline 14 & IR-79156A x WGL-347 & 92 & 88.4 & 31.2 & 219.2 & 87.5 & $\mathrm{R}$ \\
\hline 15 & IR-79156A x NLR-3042 & 88 & 90.0 & 28.6 & 198.4 & 87.4 & $\mathrm{R}$ \\
\hline 16 & IR-79156A x RNR-15398 & 99 & 83.9 & 29.5 & 201.6 & 87.2 & $\mathrm{R}$ \\
\hline 17 & IR-79156A x RNR-2781 & 91 & 91.5 & 36.5 & 245.7 & 87.1 & $\mathrm{R}$ \\
\hline 18 & IR-79156A x IR-83142-B-57-B & 91 & 84.9 & 36.1 & 238.4 & 86.8 & $\mathrm{R}$ \\
\hline 19 & IR-79156A x D-4098 & 91 & 90.5 & 29.7 & 184.8 & 86.2 & $\mathrm{R}$ \\
\hline 20 & IR-79156A x WGL-14 & 93 & 83.7 & 32.6 & 198.5 & 85.9 & $\mathrm{R}$ \\
\hline 21 & IR-79156A x RNR-2458 & 92 & 89.3 & 35.6 & 208.2 & 85.4 & $\mathrm{R}$ \\
\hline 22 & IR-79156A x RNR-15048 & 99 & 87.9 & 36.7 & 215.0 & 85.4 & $\mathrm{R}$ \\
\hline 23 & IR-79156A x RNR-15028 & 90 & 93.5 & 36.5 & 204.9 & 84.9 & $\mathrm{R}$ \\
\hline 24 & IR-79156A x NWGR-3132 & 97 & 86.7 & 42.5 & 254.9 & 85.7 & $\mathrm{R}$ \\
\hline 25 & IR-79156A x MTU-1081 & 89 & 90.0 & 26.7 & 136.4 & 83.6 & $\mathrm{R}$ \\
\hline 26 & IR-79156A x RNR-2465 & 100 & 92.5 & 23.7 & 118.0 & 83.3 & $\mathrm{R}$ \\
\hline
\end{tabular}




\begin{tabular}{|c|c|c|c|c|c|c|c|}
\hline 27 & IR-79156A x Vajram & 90 & 85.2 & 56.4 & 203.5 & 78.3 & $\mathrm{R}$ \\
\hline 28 & IR-79156A x Akshayadhan & 95 & 86.9 & 60.1 & 182.4 & 75.2 & $\mathrm{R}$ \\
\hline 29 & IR-79156A x Zhonghuai & 93 & 72.6 & 55.6 & 159.6 & 74.2 & PR \\
\hline 30 & IR-79156A x IR-83142-B-21-B & 87 & 79.6 & 58.2 & 166.7 & 74.1 & PR \\
\hline 31 & IR-79156A x NP-6226 & 102 & 82.0 & 62.8 & 175.9 & 73.7 & PR \\
\hline 32 & IR-79156A x JGL-1798 & 102 & 62.5 & 64.5 & 179.8 & 73.6 & PR \\
\hline 33 & IR-79156A x RNR-10291 & 97 & 84.6 & 56.4 & 154.6 & 73.3 & PR \\
\hline 34 & IR-79156A x JGL-11470 & 108 & 71.9 & 48.2 & 132.0 & 73.3 & PR \\
\hline 35 & IR-79156A x NLR-40058 & 93 & 86.4 & 58.4 & 159.6 & 73.2 & PR \\
\hline 36 & IR-79156A x RNR-17438 & 89 & 68.2 & 53.4 & 145.0 & 73.1 & PR \\
\hline 37 & IR-79156A x NLR-145 & 94 & 50.0 & 62.7 & 169.0 & 72.9 & PR \\
\hline 38 & IR-79156A x MGD-103 & 94 & 83.4 & 29.7 & 78.7 & 72.6 & PR \\
\hline 39 & IR-79156A x IR-64 & 104 & 50.0 & 53.7 & 132.7 & 71.2 & PR \\
\hline 40 & IR-79156A x RNR-898 & 99 & 55.0 & 79.3 & 184.6 & 70.0 & PR \\
\hline 41 & IR-79156A x C-26 & 82 & 61.8 & 66.7 & 153.3 & 69.7 & PR \\
\hline 42 & IR-79156A x RNR-17420 & 102 & 56.3 & 61.5 & 124.6 & 67.0 & PR \\
\hline 43 & IR-79156A x RNR-17494 & 92 & 73.5 & 95.6 & 184.6 & 65.9 & PR \\
\hline 44 & IR-79156A x RNR-17472 & 96 & 59.4 & 74.8 & 143.2 & 65.7 & PR \\
\hline 45 & IR-79156A x NSN-20114 & 79 & 52.0 & 92.2 & 148.7 & 61.7 & PR \\
\hline 46 & IR-79156A x NPG-210 & 94 & 64.8 & 102.4 & 124.5 & 54.9 & PR \\
\hline 47 & IR-79156A $\times$ TCA-80-A & 94 & 73.5 & 116.7 & 126.3 & 52.0 & PR \\
\hline 48 & IR-79156A x JGL-11118 & 94 & 38.6 & 107.6 & 112.9 & 51.2 & PR \\
\hline 49 & IR-79156A x Pushyami & 97 & 68.9 & 133.7 & 122.8 & 47.9 & PM \\
\hline 50 & IR-79156A x P-35 & 91 & 42.5 & 171.9 & 110.5 & 39.1 & PM \\
\hline 51 & IR-79156A x Champakali & 90 & 56.9 & 87.7 & 47.7 & 35.2 & PM \\
\hline 52 & IR-79156A x IR-83142-B-61-B & 91 & 34.4 & 163.7 & 83.9 & 33.9 & PM \\
\hline 53 & IR-79156A x RNR-11636 & 93 & 35.2 & 95.6 & 36.8 & 27.8 & PM \\
\hline 54 & IR-79156A x NSN-20894 & 102 & 43.6 & 182.4 & 64.5 & 26.1 & PM \\
\hline 55 & IR-79156A x JGL-11690 & 82 & 23.4 & 66.7 & 19.4 & 22.5 & PM \\
\hline 56 & IR-79156A x Dembersali & 88 & 42.5 & 116.7 & 16.0 & 12.1 & PM \\
\hline 57 & IR-79156A x HonneKattu & 81 & 17.5 & 224.5 & 26.7 & 10.6 & PM \\
\hline 58 & IR-79156A x CT-18664-9-10-5-6-3 & 100 & 40.5 & 133.3 & 15.7 & 10.5 & PM \\
\hline 59 & IR-79156A x CSR-23 & 93 & 17.2 & 123.4 & 5.0 & 3.9 & PM \\
\hline 60 & IR-79156A x IR-79216-141-1-3-3-3 & 99 & 1.6 & 127.6 & 3.0 & 2.3 & PM \\
\hline 61 & IR-79156A x WGL-20471 & 107 & 1.5 & 128.6 & 3.0 & 2.3 & PM \\
\hline 62 & IR-79156A x JGL-384 & 106 & 0.5 & 142.0 & 2.0 & 1.4 & PM \\
\hline 63 & IR-79156A x JGL-11727 & 112 & 1.0 & 114.6 & 0.0 & 0.0 & M \\
\hline 64 & IR-79156A x Sumathi & 104 & 0.5 & 125.6 & 0.0 & 0.0 & M \\
\hline 65 & IR-79156A x WGL-13400 & 102 & 0.2 & 137.6 & 0.0 & 0.0 & M \\
\hline
\end{tabular}

Akhter et al., (2008) observed higher frequency of maintainers $(17 \%)$ than that of restorers $(11 \%)$ in their studies. Hence, more emphasis should be given to utilize popular rice cultivars in hybrid rice breeding as parental lines to achieve the goal of superior 
hybrids. Among the 28 restorers, 12 genotypes were found to be good with more than 80 per cent fertility restorability (RNR15351, WGL-3962, IR-83142-B-57-B, RNR15398, D-4098, NWGR-3132, RNR-15028, RNR-15038, RNR-2458, RNR-2456, RNR17462 and RNR-2781). In addition to spikelet fertility the characters like pollen fertility (\%), flowering duration, plant stature and number of filled grains per panicle were taken into consideration while selection of restorers. The hybrids IR-79156A x RNR-2781, IR-79156A $x$ NWGR-3132 and IR-79156A x RNR-15038 exhibited more number of filled grains per panicle. The identified maintainers can be developed as new cytoplasmic male sterile lines by repeated back cross breeding. Twelve good restorer lines found in this study could be utilized as pollen parent for the development of new rice hybrids.

\section{References}

Akhter, M., Zahid, M.A., Sabar, M. and Ahmad, M. 2008. Identification of restorers and maintainers for the development of rice hybrids. Journal of Animal and Plant Science, 18(1): 39-41.

Ali, M., Hossain, M.A., Hasan, M.J. and Kabir, M.E. 2014. Identification of maintainer and restorer lines in local aromatic rice (Oryza sativa L.). Bangladesh Journal of Agricultural Research, 39(1): 1-12.

Bhati, P.K., Singh, S.K., Amita Sharma and Dhurai, S.Y. 2014. Identification of restorers and maintainers for different 'WA' CMS lines in rice (Oryza sativa L.). Research in Environment and Life Sciences, 7(1):53-56.

Hussain, W. and Sanghera, G.S. 2012. Exploitation of heterosis in rice (Oryza sativa L.) using CMS system under temperate conditions. Electronic Journal of Plant Breeding. 3(1):695-
700.

Jamil Hasan Md, Umma Kulsum, Niaz Md, Farhat Rahman, Tonima Farhat and Abubakar Siddique Md. 2015. Hybrid rice parental lines development utilizing different rice germplasms. Advances in Environmental Biology, 9(2):24-29.

Kumar, R.V., Satyanarayana, P. V. and Rao, M.S. 1996. New cytoplasmic male sterile lines developed in Andhra Pradesh, India. International Rice Research Notes, 21(2-3):30.

Pankaj Kumar, Vinay Kumar Sharma and Bishun Deo Prasad. 2015. Characterization of maintainer and restorer lines for wild abortive cytoplasmic male sterility in indica rice (Oryza sativa L.) using pollen fertility and microsatellite (SSR) markers. Australian Journal of Crop Science, 9(5): 384-393.

Parmeshwar Kumar Sahu, Pooja Sahu, Satyapal Singh, Tarun Singh Patel and Deepak Sharma. 2014. Identification of restorers and maintainers for development of rice hybrids using WA and Kalinga sources of CMS lines. Electronic Journal of Plant Breeding, 5(4):752-755.

Ramesh, Ch., Damodar Raju Ch., Surender Raju Ch. and Rama Gopala Varma, N. 2018. Spikelet fertility restoration studies for identification of restorers and maintainers in rice (Oryza sativa L.). Research Journal of Agricultural Sciences, 6(4): 751-753

Singh, S.K., VikasSahu, Amita Sharma and Bhati, P.K. 2013. Identification of restorers and maintainers for different wild abortive CMS lines in rice (Oryza sativa L.). Research in Environment and Life Sciences. 6(4):119-120.

Srijan, A., Sudheer Kumar, S., Damodar Raju, Ch. and Jagadeeshwar, R. 2015. 
Pollen and spikelet fertility studies for the identification of good restorers and maintainers in rice (Oryza sativa L.). Int.J.Curr.Microbiol.App.Sci., 7(3): 942-945.

Umadevi, M., Veerabadhiran, P., Manonmani, $\quad S \quad$ and Shanmugasundaram, P. 2010. Identification of potential maintainers and restorers using cytoplasmic male sterile lines in rice. Electronic Journal of Plant Breeding, 1(4): 948-952.
Veeresha, B.A., Hanamaratti, N.G., Salimath, P.M. and Chetti, M.B. 2013. Identification of restorers and maintainers for development of rice hybrids. Bioinfolet, 10(2B):602-606.

Virmani, S.S., Viraktamath, B.C., Casal, C.L., Toledo, R.S., Lopez, M.T and Manalo, J.O. 1997. Hybrid rice breeding manual, International Rice Research Institute, Philippines.

\section{How to cite this article:}

Parimala, K., Ch. Surender Raju, A.S. Hari Prasad, S. Sudheer Kumar, S. Narender Reddy and Bhave, M.H.V. 2019. Evaluation of Test Crosses for Identification of Potential Restorers and Maintainers for Development of Rice Hybrids (Oryza sativa L.). Int.J.Curr.Microbiol.App.Sci. 8(02): 1146-1151. doi: https://doi.org/10.20546/ijcmas.2019.802.133 